\title{
Incentive scheme for improving water and watershed management in Bhaktapur, Nepal
}

\author{
M Prajapati ${ }^{1^{*}}, \mathrm{~L} \mathrm{Joshi}^{2}$ \\ ${ }^{1}$ Nepal Academy of Science and Technology, Khumaltar, Nepal \\ ${ }^{2}$ Environment and Public Health Organization, Kathmandu, Nepal
}

\begin{abstract}
Fresh water is becoming scarce in many parts of the world. Deteriorating ecosystems, increasing population, changing lifestyles have intensified fresh water scarcity in many urban areas. Using Mahadev Khola watershed as a case, the present study investigates the reasons for decreasing fresh water availability in Bhaktapur municipality. Perceptions of water services among both upstream and downstream communities were collected; data of water supply and time series GIS data of land use change were analyzed. Growth in human population, urbanization, haphazard extraction of water in upstream and downstream areas, pollution of river, and damaged water pipes have led to reduction in fresh water availability in the municipality. Fresh water supply can be improved by implementing a carefully designed integrated water management master plan that incorporates ways to address all the causes of water scarcity. The master plan of Bhaktapur municipality could include an incentive mechanism, such as Payment for Ecosystem Services (PES), in which downstream consumers (municipality population, farmers and industries) provide financial and/or non-financial rewards to the upstream communities for protecting and managing forest ecosystem for water-conserving activities and for not applying hazardous agrochemicals in their fields.
\end{abstract}

Key words: land use, PES, urbanization, water scarcity

\section{Introduction}

Fresh water is becoming a scarce resource in many parts of the world. With an increasing urban population, change in food consumption and lifestyle has increased both per capita use and total water use. The scarcity of clean and fresh water is one of the world's most pressing environmental problems in many countries. Since 1950, world population has doubled, while water consumption has tripled (ECA, 2006). By 2025, more than 2.8 billion people or $35 \%$ of the world's projected population will live in 48 countries facing water stress or water scarcity (USAID, 2003). According to the UN W ater Assessment Program, by 2050, seven billion people in 60 countries may have to cope with water scarcity (Abaje et al., 2009).

Water catchments provide numerous essential ecosystem services including water for both urban and rural population. Over the past 50 years, many watersheds that provide fresh water through water purification and waterregulation services have degraded significantly (P orras et al ., 2008). The increasing scarcity of fresh water is a major pressing problem throughout the world. The population of Kathmandu Valley

\footnotetext{
*Corresponding author, email address: mediniprajapati@hotmail.com
}

is growing at the rate of nearly four percent per year (Muzzini \& Aparicio, 2013), accounting as one of the fastest-growing metropolitan areas in South Asia, and facing unprecedented challenges of rapid urbanization and moder nization. Bhaktapur district, inside the valley, has a population of 304,651 in 68,636 households (CBS, 2011). It is the second most densely populated district in the countr $y$, af ter Kathmandu. There is an acute and chronic shortage of water supply, particularly in the municipality. Generally, the local people perceive that the water availability, along with other ecosystem services, is affected by the deteriorating watershed and river ecosystems and over -exploitation of natural resources in the upstream areas.

Increasing deterioration of natural resource can be managed sustainably by promoting exploration of appropriate alternatives. The Payment of Ecosystem Ser vices (PES) schemes are emerging as an effective ecosystem management tool (WWF, 2006; Wunder. 2007; Patterson \& Coelho, 2009; Neuman et al., 2010; Joshi, 2011). The underlying principle of PES scheme is for the "downstream" beneficiaries 
of ecosystem services to finance for "upstream" conservation. In other words, the "buyers" of environmental services pay the upland "sellers" of these services. It is a market based approach, where service is provided based on demand. The four main ecosystem services that have been addressed by PES schemes are watershed services, carbon sequestration, landscape beauty, and biodiversity conservation (WWF, 2006). A number of programs - including those from China, Costa Rica, India, Mexico, and South Africa have a national scope and are financed by national governments acting on behalf of users of ecosystem ser vices throughout the countr y (Landell-Mills \& Porras, 2002).

There are more than 300 PES schemes in operation around the world. Most have a limited geographic scope and are financed directly by users of specific ecosystem services. For example, payments by downstream users of hydrological services to upstream land managers in a single watershed. In Nepal, there are numerous examples of local PES and PES-like mechanisms - watershed management for Kulekhani Hydropower Company, water supply in Dhulikhel municipality in Kavrepalanchok, Laxmi Bazaar in Gorkha, and recreation services by Kankali Community Forest User Group in Chitwan (Joshi, 2014).

The Kathmandu Valley water company 'Kathmandu Upatyaka Khanepani Limited (KUKL)' manages water collection, treatment and distribution in Bhaktapur town. The KUKL extracts surface water from two rivers: Mahadev Khola and Manohara Khola, and ground water from Jagati and Bode areas. Water from Mahadev Khola is distributed to Ward 1 to 10 and some parts of Ward 11 and 14 of the municipality. Mahadev Khola is also the main source of water for Bageswori, Nagarkot and Sudal Village Development Committees (VDCs). The town dwellers complain that the water supply is insufficient and decreasing. They blame the people living upstream area for haphazard water withdrawal and misuse. The water from the rivers is also used for irigating agriculture farms and factories located near the river in the downstream. Supplied water is both insufficient and of poor quality (KUKL Officials, Personal Communication).

According to WEC S (2011), climate change impacts are observed in several sectors of Nepal, among which water resources is one of the hardest hit sectors. Climate change can be another potential cause that may affect water availability in rivers and lak es. L ocal war ming with a corresponding decrease in $r$ unoff could have adverse consequences on the water demand side (Jose et al., 1999). The exact reasons for reduction in the quantity and quality of water supplied in Bhaktapur town have not been properly explored. Furthermore, if the problem of water scarcity is because of improper land and water management in the upstream area of Mahadev Khola watershed, then this can be addressed through a good local PES mechanism as in other places inside and outside Nepal. The present study was carried out with the aim of assessing the water scarcity problem and evaluating the potential of PES scheme to improve water services in Bhaktapur Municipality.

\section{Materials and Methods}

Mahadev Khola Watershed (MKW) is located in the eastern region of the Bhaktapur District (Fig. 1). Mahadev Khola is a stream originating from Mahadev Pokhari located near the top of Nagarkot hill in the Mahabharat (mid-hill) range. The river is only about $10 \mathrm{~km}$ long with catchment area of 11 $\mathrm{km}^{2}$ and annual water yield of 19 million cubic meters (Sada, 2010). It is recharged by a catchment area encompassing seven community forests (CF) of Bageswori VDC, Nagarkot VDC, Sudal VDC and a part of Kavrepalanchok district. The stream has been dammed by weir in Bageswori VDC to fom Mann Pokhari (pond) that is used for supplying drinking water in the Bhaktapur municipality. The population of the three VDCs is 15,617 in 2011, while there are 64,810 people living in ward no. 1 to 10 , parts of 11 and 14 of the municipality.

Reconnaissance observations were made visually to assess the condition of the watershed. Landuse and landuse change data for MKW were collected from secondary sources and analyzed using Arc GIS 9.3. Primar y data were collected through direct observations, focus group discussions and key informant interview. Focus group discussion was done in three VDCs lying in Mahadev Khola watershed, located in Bhaktapur district. However, for the analysis of water scarcity area and water sufficiency area the discussion were conducted in Bhaktapur municipality. Likewise, for the key informant interview, different institutional authorities were selected. The secondary data were obtained from KUKL and other gover nment and non-gover nment organization.

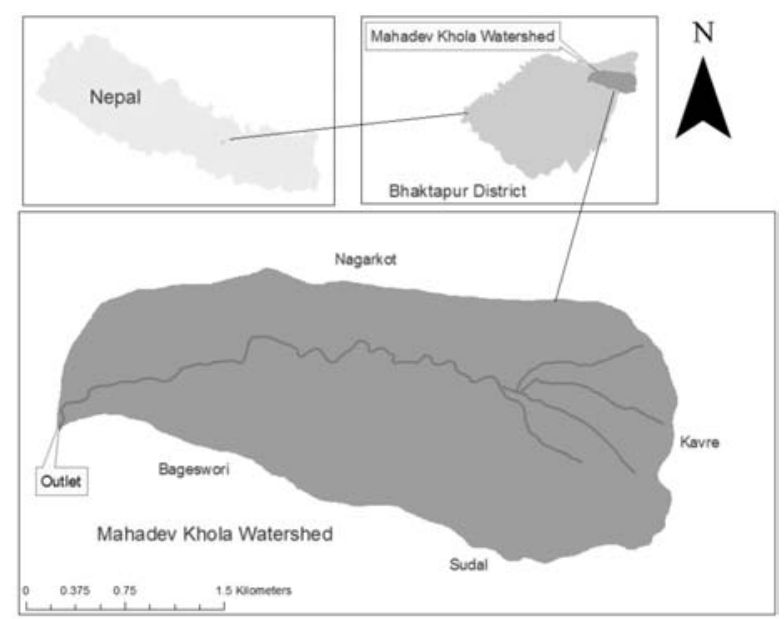

Fig. 1 Mahadev Khola Watershed 


\section{Results and Discussion Landuse change}

The comparative analysis of topographic map of 1992 and Google Earth Map of 2010 revealed that contrary to a general trend of deforestation in many parts of Nepal, the situation in MKW is reverse. In MKW, some of the non-forest areas including human settlements and agriculture land, existed in 1992 have reverted back to forest area by 2010 (F ig. 2). The time series land-cover data show a reversal trend from non-forest land to forest in MKW. Out of the total watershed area of $6.98 \mathrm{~km}^{2}$, forest area increased from $5.85 \mathrm{~km}^{2}$ in 1992 to $6.41 \mathrm{~km}^{2}$ in 2010 . The increase in forest land is mainly due to the reforestation of parts (about $0.56 \mathrm{~km}^{2}$ ) of the previous non-forest area that decreased from $1.14 \mathrm{~km}^{2}$ in 1992 to $0.57 \mathrm{~km}^{2}$ in 2010 (This is because of re-alignment of forest border in 2007). This also supports the claim made by the District Forest Office (DFO), Bhaktapur for having a substantial increase in forest area in Nagarkot over the last two decades. Significant change was seen in Nagarkot Wards1, 2, 3 and 6, managed by Aaindanda Community Forest User Group (Table 1). The success of the community forestr y program and the role of local community in the catchment have been instrumental in forest restoration and management over the last two decades. Due to the short nature of the study, the effect of increasing forest area on water quality and regulation could not be empirically ascertained. Based on scientific knowledge, it is assumed that the forest ecosystem and water related services in the catchment area should have improved, including the regulation and quality of water.
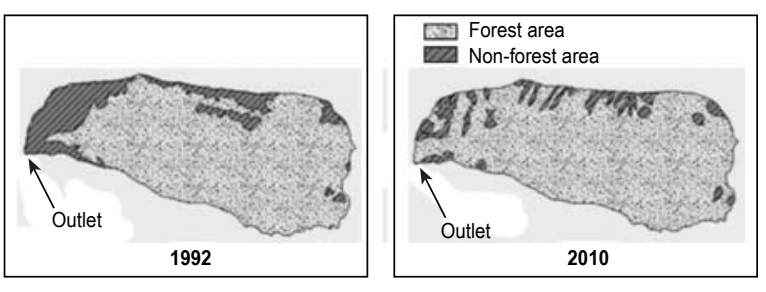

$0 \quad 875,1750, \quad, 3500$ meters

Fig. 2 Forest covers in Mahadev Khola watershed in 1992 and 2010.

\section{Water Services}

Interviews with upstream and downstream communities to better understand their perception about different causes and effects related to water system in MKW revealed various interlinked factors leading to water conflict (Fig. 3).

The (over) use of water in upstream area, including ar my barrack, increasing human population, and farming are the primary causes of reduced quality and quantity of water in the reservoir. Though KUKL has regulated different projects to find the alternative sources of water (Katunje and Decoca projects as alter native water sources have failed), the households in town are also looking for alternative sources of waters (Buying water tank ers or jars). In absence of alternative sources of water for a growing urban population, water scarcity problem is increasing in the municipality. This has resulted in local conflicts for water. Over-extraction of water in the upstream area, disposal of untreated sewerage and solid waste directly into the river, development of urban infrastructure and services with complete disregard for the river environment are some of the problems in Bhaktapur urban planning (Sada, 2010).

In discussion, the local people said that the pine trees (Pinus spp.) planted on a lar ge scale have reduced both the availability and quality of water in the area. Similar claims were made by local farmers in Kulekhani watershed, where pine trees were extensively planted in community forests, in 1980s (Shyam Upadhyay, personal communication). Moran et al. (2000) indicated that there was an $82 \%$ reduction in streamflow in the KwaZulu-Natal Drakenberg after 20 years of pine plantation; a 55\% reduction in streamflow (from 600 to $270 \mathrm{~mm}$ ) in Fynbos catchments in the Western Cape after 23 years of planting pines; and the complete dr ying up of streams after 6-12 years of replacement of catchments grassland with pines and eucalypts in the Mpumalanga Province of South Africa. Both upstream and downstream communities seem to be aware about linkage between watershed conservation and hydrological benefits. Replacing pine trees with local broad-leaf species and improving forest cover have been realized to be good for hydrological services of the catchment.

Table1: Total area of community forest of Mahadev Khola watershed.

\begin{tabular}{lllll}
\hline S.N & Name of CF & VDC/ Ward no. & Forest area (ha) in 1996 & Forest area (ha) now in 2007 \\
\hline 1. & Bahal CF & Bageswori-3, 4,5 & 52.1 & No Change \\
2. & Bahal CF & Bageswori-5, 6 & 63.5 & No Change \\
3. & Bahal CF & Sudal -7 & 69.03 & No Change \\
4. & Mahamanjushree CF & Sudal -6 & 38.76 & No Change \\
5. & Aaindada CF & Nagarkot- $1,2,3,6$ & 25.5 & 34 \\
6. & Lakhane CF & Nagarkot -7, 8 & 3.69 & No Change \\
7. & DhungePakha and & Bhaktapur -8 and & 103 & No Change \\
& NalaTukucha CF & Kavre -5 & & \\
\hline
\end{tabular}

Source: DFO Bhaktapur (2011) 


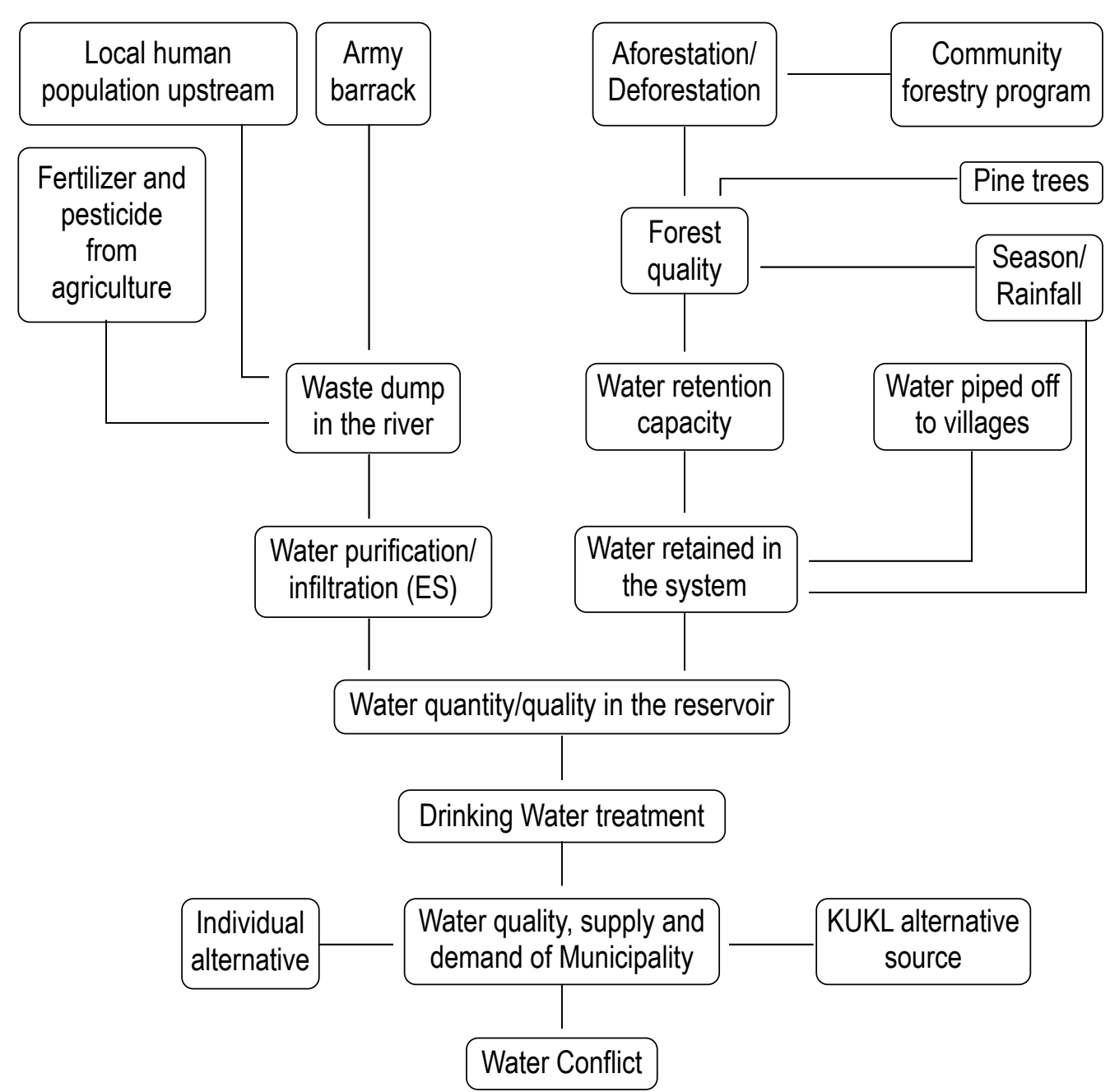

Fig. 3 Cause and effect pathway in water services in Mahadev Khola watershed

\section{Water availability}

The people of Bhaktapur Municipality (downstream population) are facing a chronic shortage of water particularly in the dry season. However, drinking water facility is available to all settlements in upstream area, where water is extracted directly using pipes that transfer water from springs to public and private taps. The number of private taps has increased substantially in recent years. The amount of water extracted from the river is significant (up to 70\%), especially in the dry season, with a direct impact on the water available in the springs and downstream river, as exemplified by the data for 2010-11 (Fig. 4).

The wet (monsoon) season in Nepal commence from midJune to mid-September, when over two-thirds of the total annual rain falls throughout the countr y. The remaining months are relatively dry. According to KUKL, about 30\% of annual water is extracted from Mahadev Khola in the wet season; while $70 \%$ in the dry season when there is less water in the river. This is an indication of the pressure on the river system primarily during the $\mathrm{dr}$ y season. The total river discharge for fiscal year 2010-2011 was estimated to be 1009 Million Litre (ML), of which 575 ML was extracted by KUKL.

Water supply in Bhaktapur municipality from Mahadev Khola is $4.5 \mathrm{ML} / \mathrm{d}$ in the wet season and it is only $1.5 \mathrm{ML} / \mathrm{d}$ in the dry season, whereas the current demand is estimated to be $8 \mathrm{ML} / \mathrm{d}$ (Personal communication with KUKL officials). Wells, ponds and stone waterspouts used to be the primary source of water in Bhaktapur municipality. However, many of these have now dried up. The local people still use existing wells and waterspouts; and new wells are being dug. However, water scarcity is increasing. During the dry season, people have to buy water from private tankers. 
In 2001, the population of upstream area was 8,390 who used to consume $0.4 \mathrm{ML}$ of water per day . In 2011, this population increased to 11,212 and water consumption reached $0.5 \mathrm{ML} / \mathrm{d}$. Similarly, the downstream population was 50,008 in 2001 with the consumption of $3 \mathrm{ML} / \mathrm{d}$. By 2011, the population reached to 66,832 with water consumption 4 ML per day. In an interval of 10 years, the consumption of water has increased from $3.4 \mathrm{ML} / \mathrm{d}$ to $4.5 \mathrm{ML} / \mathrm{d}$. Changing lifestyles in recent period, mainly in the urban areas, has been attributed for increased water consumption.

The upstream communities extract clean water directly from existing source and new springs. The water is used for both household consumption and irrigation. It was also noticed that far mers in the upstream area practice intensive agriculture and apply agrochemicals which demand more water and also pollute the river water available for Bhaktapur municipality. The efficient use of water in upstream can reduce water wastage making more water available for downstream. The water distributed in the municipality is generally turbid and of low quality. The river water in the rainy season carries not only the fine sediments, the water extracted and supplied through pipes are further contaminated due to damage and leaks in the water pipes. The town dwellers nor mally boil and filter water before consumption. Some households also use Aluminium sulphate $\left(\mathrm{Al}_{3} \mathrm{SO}_{4}\right)$ commonly called 'alum', bleaching powder, caustic soda, and lime to treat tap water. The water distribution pipes were installed 40-50 years ago. Thus, leaks and breakage in the pipes are a major problem causing loss of water and its quality.

Water availability has decreased in the municipality and conflicts related to water are common. The supply of water has declined and demand has increased. This situation is aggravated by haphazard extraction of water for farming and irrigation as well as pollution of river water by human activities and local industries.

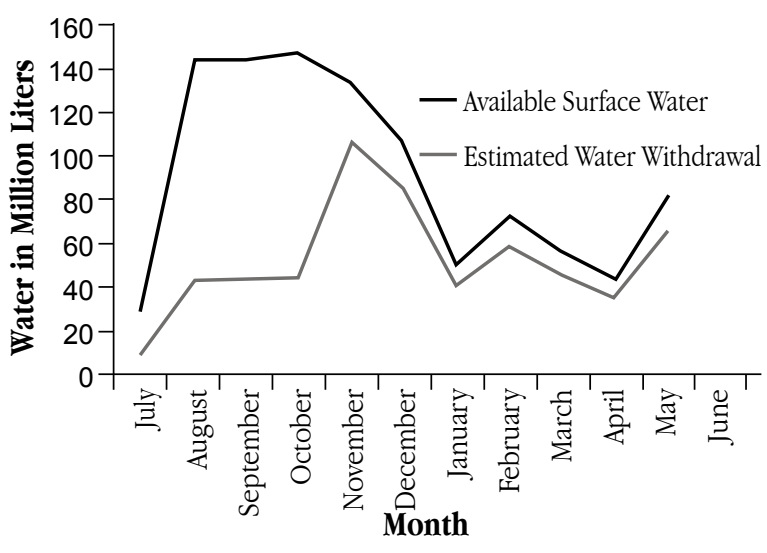

Fig. 4 Surface water flow and estimated water withdrawal in fiscal year 2010/11 (Source: KUKL, 2010)
Potential of Payment for Ecosystem Serivice

Development of a sustainable and equitable payment mechanism appears feasible. There is clear willingness of the downstream water consumers to invest in conservation activities, such as planting of open land with trees, replacement of pine trees with broadleaf species, efficient use of water and reducing pollution that will all result in enhanced ecosystem services. Financial and/or non-financial rewards to upstream communities can be provided if forest enhancing and water conserving activities are conducted by the upstream communities. Although PES concept advocates performance based system (e.g. evidence to show increase in dry season flow in the river), the conservation activities can be considered sufficient indicators to allow payments. The payments (e.g. environment fee added in the water bill, ecosystem service tax: to visitors (picnickers, hikers) MKW upstream area), from water users in Bhaktapur town, famers and factories along the river could be collected into PES fund. This fund may be used to provide rewards to upstream communities for not wasting water and properly managing their community forests by maintaining good forest cover, planting water storing species inside the forests, not degrading their forest resources and not haphazardly applying agrochemicals (fertilizers and pesticides) in the agriculture crops. Water extraction directly from river by far mers and factories should be regulated and a fee could be char ged.

The public sector, acting on behalf of and in the interest of civil society, has a $\mathrm{k}$ ey role to play in the protection of ecosystem services as public goods, by establishing standards and regulations for their use ('command-and-control' approach), by leveling the mark et prices and providing positive incentives (Joshi, 2011). Negotiation between buyers (downstream) and sellers (upstream) will require facilitation and support of at least one intermediary. The study indicates the preference of buyers and sellers for the engagement of Bhaktapur Municipality. As KUKL also has a direct interest in the development and outcome any PES scheme, it can also take an active role as facilitator and ecosystem service monitoring agent in the PES scheme.

Many countries around the globe are implementing different schemes for collecting payment to finance watershed protection. In Nepal, though few random efforts towards feasibility studies and setting up PES mechanism have been made in recent years, it still remains fairly a new concept. There exists vast opportunity for Nepal to tap these interests, and facilitate with proper policy responses to benefit conservation as well as poverty alleviation issues (Paudel, 2010). In case of Bhaktapur water scarcity problem, water management of urban areas is the responsibility of municipality and it should develop an integrated master plan and funding required for the rehabilitation of water system in urban areas and policy should be made to meet future demands for water. An appropriate PES scheme ought to be a part of the master plan. 


\section{Conclusion}

Mahadev Khola Watershed can provide necessary volume of water if water collection and distribution systems are properly managed. It is possible to increase watershed services, including water regulation and quality improvement, through an appropriate PES scheme. Incentive scheme may include efficient use of water (not wasting) and good management of community forests and not haphazardly applying agrochemicals (fertilizers and pesticides) in their fields. Experience of PES schemes elsewhere indicates sufficient potential for use in Bhaktapur water supply system.

\section{Acknowledgements}

The authors would like to acknowledge Khwopa College, Bhaktapur and Mr. Kamal Raj Gosai, for their support. Likewise, the help from KUKL-Bhaktapur , Bhaktapur municipality and other institutions is highly appreciated. The authors owe special thanks to all the local respondents for their time and contribution.

\section{References}

Abaje, I.B., Ati O.F \& Ishaya, S. (2009). Nature of PotableAbaje, I.B., Ati O.F. \& Ishaya, S. (2009). Nature of Potable Water Supply and Demand in Jema'a Local Government Area of Kaduna State, Nigeria. Research Journal of Environmental and Earth Sciences, 1, 16-21.

CBS. (2011). Population census. Central Bureau of Statistics. HMG, Nepal.

Chenoweth, J. (2008). Water, water everywhere. New Scientist, August 2008, 28-32.

DFO Bhaktapur. (2011). District Profile. District Forest Office, Bhaktapur, Nepal.

KUKL. (2010). KUKL at a glance. Third Anniversary.Kathmandu Upatyaka Khanepani Limited (KUKL), Bhaktapur, Nepal.

ECA. (2006). Water in Africa: Management option to enhance the survival growth. Prepared by The New Partnership for Africa Development (NEPAD), Economic Commission of Africa.

Joshi, L. (2011). Community-based PES for forest preservation and sediment control in Kulekhani, Nepal. In: Payments for ecosystem services and food security. FAO, 198-203.

Joshi, L. (2014). Ecosystem Services and Payment Schemes. Swocha Batabaran. Swocha Batabaran Manch, Bhaktapur, Nepal. pp 46-48.

Landell-Mills, N., \& Porras, I. T. (2002). Silver Bullet or fool's gold? A globle review of markets for forest environmental services and their impact on the poor. IIED, London. pp. 249.
Moran,V. C., Hoffmann, J. H., Donnelly, D., Van Wilgen, B. W., \& Zimmermann, H. G. (2000). Biological Control of Alien, Invasive Pine Trees (Pinus sp) in South Africa: Proceedings of the X International Symposium on Biological Control of Weeds 9414-14 July 1999, Montana State University, Bozeman, Montana, USA Neal R. Spencer [ed.]. pp. 941-953.

Muzzini, E., \& Aparicio, G. (2013). Urban Growth and Spatial Transition in Nepal: An Initial Assessment. World Bank: pp.160.

Neuman. F., Keenan, L., Sherchan, U., Sander, K., Joshi, L., Huberman D., \&.Karky, B.S. (2010). Payments for Environmental Services in Mountain Areas: An Overview of the Options and Challenges for Mountain Systems and People. Mountain Forum Bulletin 1. Mountain Forum Secretariat, World Agroforestry Centre (ICRAF), IUCN, ICIMOD and the World Bank. Kathmandu, Nepal.

Patterson, T.M., \& Coelho, D. L. (2009). Ecosystem services: Foundations, opportunities, and challenges for the forest products sector. Forest Ecology and Management, 257, 1637-1646.

Paudel, D. (2010). Study report of Economic valuation of Watershed Services and Payment for Environmental Services (PES) Scheme for Sardu Watershed Conservation. UK Aid from the Department of International Development.

Porras, I., Grieg-Gran, M., \& Neves, N. (2008). All that glitters: A review of payments for watershed services in developing countries. Natural Resource Issues No. 11. IIED, London, UK.

Sada, R. (2010). Processes and Consequences of the Degradation of Hanumante River: Religious, Cultural and Livelihood Impact. MSc Thesis. Center for Postgraduate Studies, Nepal Engineering College, Pulchowk, Lalitpur, Nepal.

USAID. (2003). Investments in Drinking Water Supply and Related Activities: A Report to the U.S. House and Senate Appropriations Committees.

WECS. (2011). Water Resources Sources of Nepal in the context of Climate Change. Water and Energy Commission Secretariat, Kathmandu, Nepal.

Wunder, S. (2007). The efficiency of payments for environmental services in tropical conservation. Conservation Biology, 21, $48-58$.

WWF. (2006). Payments for Environmental Services: An equitable approach for reducing poverty and conserving nature. World Wildlife Fund for Nature. 